\title{
Reformulasi Tafsir: Studi Pemikiran Gender Asghar Ali Engineer
}

\author{
ABDUL RASYID RIDHO \\ UIN MATARAM \\ rasyidalridho@uinmataram.ac.id
}

\begin{abstract}
Asghar Ali Engineer is one of the figures who promotes and implements liberation theology. Liberation theology emphasizes praxis rather than metaphysical theoritization which includes abstract and ambiguous concepts. The praxis in question is of a liberal nature and involves dialectical attraction between "what is" and "what should be". As well as this ambiguous meaning that opens opportunities for flexibility in making creative and constructive changes. This theology is applied, among others, related to the injustice towards women. Women realize that they have not really been 'individualized', have not been treated as whole human beings. This condition is of course felt as a confinement that shackles women. So from a normative perspective, it is clear that the Koran upholds the principle of equality between men and women. In other words, the Qur'an is very concerned with issues of gender equality. However, when viewed from a contextual perspective, the alQur'an sometimes places men one level above women.
\end{abstract}

Keywords: Asghar Ali Enginer, Theology of Liberation, al-Qur'an.

\section{A. Pendahuluan}

Fakta bahwa kemiskinan, keterbelakangan, kebodohan, ketertindasan, ketidakadilan, dan semacamnya hingga tingkat tertentu masih merupakan realitas keseharian sebagian besar umat Islam di belahan dunia manapun, tidak terkecuali di Indonesia. 
Banyak hal bisa dituding sebagai penyebabnya, baik dari aspek sumber daya manusianya atau pun pada ranah sistem pemerintahannya yang dinilai masih gagal dalam menyelesaikan berbagai problema yang ada. Namun, terlepas apapun prime cause dari realitas dimaksud, impotensi umat Islam menghadapi kenyataan itu tentu ironis demi menyadari betapa sesungguhnya Islam sarat akan spirit revolusioner, nilai-nilai moral yang membebaskan, yang mendorong ke arah terciptanya tatanan hidup yang lebih baik, layak, dan manusiawi.

Termasuk masalah kaum wanita agaknya tidak kunjung berakhir. Kehidupan wanita memang mempunyai kekhususan sendiri yang menarik untuk diperbincangkan. Akan tetapi kekhususan itu bagi kaum wanita sendiri tidak selalu berarti sesuatu yang menyenangkan. Memang dengan kekhususan itu dalam banyak hal dirasa tidak adil. Kaum wanita merasa hidup bukan dalam dunia yang sepenuhnya dunia mereka sendiri. Dunia ini dianggap adalah dunia yang didominasi laki-laki.

Kondisi ketidaksetaraan dirasakan kaum wanita sebagai ketidakadilan. Kaum wanita sadar bahwa mereka belum benarbenar 'diorangkan' atau belum diperlakukan sebagai manusia seutuhnya. Kondisi seperti ini tentu saja dirasakan sebagai kungkungan yang membelenggu kaum wanita.

Tantangan besar yang dihadapi oleh kaum wanita adalah legitimasi teologis terhadap kondisi yang mereka rasakan tidak adil, sehingga apa yang dilakukan dianggap bertentangan dengan 
ajaran agama. Dalam hal ini, muncul seorang tokoh dari India yang turut serta menyuarakan suara kaum wanita. Dia adalah Asghar Ali Engineer. Asghar mempunyai pemikiran yang berbasis pembebasan. Dia menerapkan pemikiran dasar ini dalam berbagai aspek, termasuk pembebasan kaum wanita dari ketidakadilan kaum laki-laki.

Di bawah ini kami mencoba memaparkan beberapa hal mengenai Asghar Ali Engineer, baik biografi, latar belakang pemikiran, pemikiran tafsir, sampai contoh penerapan pemikiran teori yang dibangun terkait dengan pembebasan perempuan.

\section{B. Pemikiran Asghar Ali Engineer}

\section{Biografi Asghar Ali Enginer}

Asghar Ali Engineer lahir di India. Ia merupakan pemikir muslim, penulis sekaligus merupakan seorang aktivis. Ashgar dikenal dengan diskursusnya mengenai Teologi Pembebasan. Asghar, lahir pada tanggal 10 Maret 1939 di Salumbar, Rajastan India. ${ }^{1}$ Ayahnya, Shaikh Qurban Hussain merupakan seorng pemuka agama, pemimpin kelompok Daudi Bohras. Ketika mempelajari Tafsir dan Ta'wil Al-Qur'an, Fiqh, Hadis, dan Bahasa Arab, Ashgar juga banyak membaca karya-karya Bettrand Russel dan Karl Marx. Ia bahkan mengaku telah membaca habis buku Das Kapital karya Marx. ${ }^{2}$ Bacaan ini sedikit banyak terbukti mempengaruhi analisa

${ }^{1}$ Agus Nuryanto, Islam, Teologi Pembebasan an Kesetaraan Gender: Studi atas Pemikiran Asghar Ali Engineer, Yogyakarta: UII Press, 2001, hlm. 7.

${ }^{2}$ Asghar Ali Engineer, Islam Masa Kini, Yogjakarta: Pustaka Pelajar, 2004, hlm. vii. 
dan gagasannya, yang kini dikenal identic dengan diskursus "khas kiri" seperti ketidakadilan, penindasan, revolusi, perubahan radikal, dan sebagainya.

Sebagai seorang pemikir-reformis, lebih-lebih kapasitasnya sebagai Directur of Islamic Studies di Bombay, dan mantan anggota Dewan Eksekutif Universitas Jawaharlal Nehru, di India, Asghar sangat rajin dalam menuangkan ide-ide pemikirannya di berbagai forum ilmiah baik dalam seminar, perkuliahan, lokakarya, maupun simposium di berbagai negara. Bahkan dalam mensosialisasikan pemikirannya, Asghar Ali Engineer aktif menulis maupun sebagai penyunting di berbagai penerbitan.

Dengan memahami posisi Asghar Ali Engineer di atas, maka tidaklah mengherankan mangapa ia sangat vokal sekali dalam memperjuangkan dan menyuarakan pembebasan. Suatu tema yang menjadi ruh pada setiap karyanya, seperti hak asasi manusia, hakhak wanita, pembelaan rakyat tertindas, perdamaian etnis, agama, dan lain-lainnya. Itulah sebabnya, ia banyak terlibat bahkan memimpin organisasi yang memberikan banyak perhatian kepada upaya advokasi sosial. Meskipun harus bertentangan dengan generasi tua yang cenderung bersikap konservatif, dan pro status qou. Hal ini terjadi ketika sekte Daudi Bohra dipimpin oleh Sayyidina Muhammad Burhanuddin yang dikenal sebagai Da'i mutlak (absolute preacher). ${ }^{3}$

${ }^{3}$ M. Agus Nuryatno, Islam,Teologi Pembebasan dan Kesetaraan Gender, Cet.I, Yogyakarta: UII Press, 2001, hlm. 8. 


\section{Metode Penalaran al-Qur'an}

Tidak dapat dipungkiri oleh Engineer sendiri, bahwasannya al-Qur'an adalah kitab suci pertama yang mengangkat derajat perempuan sedemikian rupa di saat perempuan dilecehkan oleh peradaban besar seperti Byzantium dan Sassanid. Al-Qur'an banyak sekali memberikan perhatian terhadap perempuan, seperti dalam masalah perkawinan, perceraian, kekayaan, dan warisan.Karena itu, masa Nabi merupakan masa yang ideal bagi kehidupan perempuan.Mereka dapat berpartisipasi secara bebas dalam public tanpa dibedakan dengan laki-laki.

Namun paska Nabi, tepatnya masa Umar, perempuan mulai dibatasi aktifitasnya.Beliau mengeluarkan kebijakan yang memojokkan perempuan, misalnya memaksa perempuan Muslim untuk tetap di rumah mereka masing-masing dan mencegah kehadiran mereka di masjid. ${ }^{4}$ Perlakuan tidak adil terhadap perempuan tersebut pada perjalanan sejarah semakin terasa. Jadilah kemudian hak-hak perempuan tersubordinasi lakilaki.Dengan demikian Engineer merasa perlu untuk melakukan reinterpretasi terhadap al-Qur'an agar nilai-nilai kesetaraan dan keadilan yang menjadi prinsip dasar al-Qur'an dapat lebih dikedepankan daripada hal-hal yang bersifat legal-formal.

Dalam melakukan interpretasi terhadap al-Qur'an yang berbicara tentang perempuan, Engineer mempunyai 3 hal penting yang menjadi perhatian:

${ }^{4}$ M. Agus Nuryatno, Islam, Teologi Pembebasan dan Kesetaraan Gender Studi atas Pemikiran Engineer Ali Engineer,Yogyakarta:UII Press, 2005, hlm. 61. 
a) Membedakan ayat-ayat al-Qur'an yang mempunyai aspek normatif dan kontekstual. Ini penting dilakukan dalam memahami al-Qur'an. Aspek normatif merujuk pada sistem nilai dan prinsip-prinsip dasar dalam Al-Qur'an. Contoh prinsip ini adalah ayat-ayat al-Qur' an yang berbicara tentang persamaan, kesetaraan, dan keadilan. Prinsip-prinsip ini bersifat eksternal dan dapat diaplikasikan dalam pelbagai konteks ruang dan waktu. Adapun aspek kontekstual dalam al-Qur'an berkaitan dengan ayat-ayat yang diturunkan untuk merespon problem-problem sosial tertentu pada masa itu. Seiring dengan perkembangan zaman, ayat-ayat tersebut dapat diabrogasi. Dalam pandangan Engineer, aspek normatif lebih mempunyai kedekatan dan kesucian, sementara aspek kontekstual lebih dekat kepada manusia.

Dilihat dari perspektif normatif, terlihat dengan jelas bahwasannya al-Qur'an menegakkan prinsip persamaaan derajat antara laki-laki dan perempuan. Dengan kata lain, alQur'an sangat concern dengan persoalan kesetaraan gender. Akan tetapi, jika dilihat dari perspektif kontekstual, alQur'an kadang-kadang mendudukkan laki-laki satu tingkat di atas perempuan.

Tujuan lain yang tidak kalah pentingnya dalam membedakan hal tersebut adalah mengetahui perbedaan apa yang sebenarnya diinginkan oleh Allah dan apa yang dibentuk oleh realitas empiris masyarakat pada waktu itu. Keduanya 
tentu saja sama-sama merupakan kekayaan al-Qur'an, karena al-Qur'an tidak hanya concern terhadap masyarakat ideal, akan tetapi juga mempertimbangkan realitas empiris. ${ }^{5}$

b) Penafsiran ayat-ayat al-Qur'an sangatlah tergantung kepada persepsi, pandangan dunia, pengalaman, dan latar belakang sosio-kultural di mana mufassir itu tinggal. Engineer mengatakan bahwasannya penafsiran terhadap fakta empiris atau teks kitab suci selalu tergantung kepada posisi apriori seseorang. Setiap seseorang memiliki semacam weltanschauung. Dengan melihat ketergantungan tersebut, dapat dikatakan bahwasannya penafsiran yang murni terhadap kitab suci tidaklah mungkin. Penafsiran selalu dipengaruhi oleh situasi-situasi soaiologis, dan tidak ada seseorangpun yang bisa lepas dari pengaruh tersebut. Menjadi suatu yang biasa jika satu ayat dapat memberi inspirasi bagi beragam tafsir, khususnya ketika yang mendekati teks tersebut adalah orang dengan latar belakang historis yang berbeda.

c) Makna ayat-ayat Al-Qur'an itu terbentang oleh waktu. Oleh karena itu, penafsiran ulama-ulama klasik yang terdahulu mempunyai beberapa perbedaan dengan hasil penafsiran ulama-ulama modern. Ini dapat terjadi karena memang AlQur'an menggunakan bahasa simbolik atau metaforis yang punya makna ambigu. Makna yang ambigu inilah yang

${ }^{5} \mathrm{M}$. Agus Nuryatno, Islam, Teologi Pembebasan dan Kesetaraan Gender Studi atas Pemikiran Engineer Ali Engineer, hlm. 62. 
membuka peluang fleksibilitas dalam melakukan perubahan yang kreatif dan konstruktif. Engineer dalam hal ini mengajak untuk menafsirkan bahasa simbolik dalam AlQur'an dari sudut pandang situasi historis dan pengalaman orang yang ingin menafsirkan Al-Qur'an itu sendiri. ${ }^{6}$

Tiga poin tersebut di atas harus dipertimbangkan ketika hendak memahami Al-Qur'an.Engineer menyarankan untuk lebih mengedepankan aspek normatif daripada aspek kontekstual, dengan alasan aspek normatif sarat dengan nilai-nilai dan prinsipprinsip yang menjadi postulat dasar kitab suci tersebut.Adapun ayat-ayat kontekstual, maka harus ditafsirkan secara ketat dari sudut pandang konteks sosio-historis di mana ayat-ayat tersebut diturunkan.Termasuk di dalamnya adalah memahami posisi kaum perempuan pada konteks masyarakat tersebut.Pertimbangan sosiologis semacam itu, menurut Engineer sangat penting dilakukan jika kita hendak memahami makna yang tersembunyi di balik teks Al-Qur'an.Tanpa memperhatikan dan menerapkan ketiga poin tersebut, tampaknya sangat sulit untuk membuat sebuah kesimpulan yang benar.

Bila kita membandingkan metodologi Engineer dengan penafsir kontemporer lain seperti Fazlur Rahman, Aminah Wadud dan Fatima Marnissi, maka kita dapat merasakan bahwasannya metodologi yang digunakan Engineer lebih sederhana. Namun demikian, elaborasinya tentang pembedaan antara ayat-ayat

${ }^{6} \mathrm{M}$. Agus Nuryatno, Islam, Teologi Pembebasan dan Kesetaraan Gender Studi atas Pemikiran Engineer Ali Engineer,... hlm. 63. 
normatif dan kontekstual sangatlah penting. Dengan pembedaan tersebut, orang akan dapat membedakan antara nilai-nilai fundamental yang menjadi spirit dasar Al-Qur'an dan nilai-nilai kontekstual yang terikat oleh ruang dan waktu sehigga tidak bisa berlaku secara universal. ${ }^{7}$

\section{Konsep Teologi Pembebasan Asghar Ali Engineer}

Teologi Pembebasan adalah kata majemuk dari teologi dan pembebasan. Secara etimologis, teologi berasal dari theos yang berarti Tuhan dan logos yang berarti ilmu. Teologi adalah ilmu yang mempelajari tentang Tuhan dan hubungannya dengan manusia dan alam semesta.Sedangkan kata pembebasan merupakan istilah yang muncul sebagai reaksi atas istilah pembangunan (development) yang kemudian menjadi ideologi pengembangan ekonomi yang cenderung liberal dan kapitalistik dan umum digunakan di Negara dunia ketiga sejak tahun $60-$ an. $^{8}$

Sebelum dijelaskan lebih jauh seputar teologi pembebasan ada baiknya kalau kita simak beberapa pendapat tentang pemaknaan terhadap Teologi pembebasan.Menurut Asghar Ali Engineer, Teologi Pembebasan mengandung unsur pokok sebagai berikut; pertama, Teologi Pembebasan dimulai dengan melihat kehidupan manusia di dunia dan Akhirat.Kedua, Teologi ini tidak menginginkan status quo yang melindungi golongan kaya yang

${ }^{7}$ M. Agus Nuryatno, Islam, Teologi Pembebasan dan Kesetaraan Gender Studi atas Pemikiran Engineer Ali Engineer, hlm. 64.

${ }^{8}$ Francis Wahono Nitiprawiro, Teologi Pembebasan, Sejarah, Metode, Praksis dan Isinya, Yogjakarta: LKiS, cet. II, 2008, hlm. 8-9. 
berhadapan dengan golongan miskin. Dengan kata lain teologi pembebasan itu anti kemapanan (establishment), apakah itu kemapanan religius atau kemapanan politik yang menindas. Ketiga, Teologi pembebasan memainkan peranan dalam membela kelompok yang tertindas dan tercabut hak miliknya dan memperjuangkan kelompok ini dan membekalinya dengan senjata ideologis yang kuat melawan golongan yang menindasnya.Keempat, Teologi pembebasan tidak hanya mengakui satu konsep metafisika tentang takdir dalam rentang sejarah umat Islam tetapi juga mengakui konsep bahwa manusia itu bebas menentukan nasibnya sendiri. ${ }^{9}$

Di sini Teologi Pembebasan mencoba melakukan transformasi antara pendekatan kosmologis dengan pendekatan empiris.Artinya Aspek Ketuhanan dalam beragama tidak hanya berhenti pada praktik beragama yang individualis, tetapi mempunyai konsekuensi logis untuk melakukan perubahan sosial terhadap ketidakadilan. Teologi pembebasan mencoba mencapai tujuannya lewat suatu proses yang bebas dan partisipatif. Kerangka yang dibangun adalah pembacaan terhadap realitas sosial. Membaca disini tidak hanya berhenti pada dataran teks (qouliyah) tetapi juga melakukan pembacaan yang sifatnya kontekstual (kauniyah).

Teologi pembebasan memberikan prioritas yang mutlak pada praksis diatas teori.Tujuannya adalah untuk merubah satus quo

${ }^{9}$ Asghar Ali Engineer, Islam dan Teologi pembebasan, Jogjakarta: Pustaka Pelajar,2003, hlm. 1-2. 
bukan untuk mempertahankannya. Dalam hal ini Maulana Ibrahim Moosa seperti yang dikutip oleh Farid Essack menekankan hubungan antara praksis dengan teori pembebasan sebagai berikut: Praksis pembebasan berlawanan dengan praktik harus menjadi semboyan kita. Praksis berarti melakukan dan merefleksikan halaqat mesti menjadi lingkaran aktif pengetahuan dan praksis yang menyatukan kaum intelektual organik (alim/ulama) dengan aktifis (mujahid) untuk memenuhi deskripsi komunitas muslim awal yang gagah berani, disiang hari bagaikan singa dan menjadi rahib-rahib di malam hari. ${ }^{10}$

Di sini praksis pembebasan menjadi penting karena inti dari transformasi sosial itu adalah adanya kerja rill untuk melakukan pembebasan dari ketidakadilan ekonomi, politik, gender, rasialis dan bentuk-bentuk penindasan lainnya.Hanya saja dalam praktiknya, praksis pembebasan melakukan suatu tindakan semacam evaluating proceesing yang dalam bahasanya Budhi Munawar Rachman disebut Refleksi Teologi (Theology Reflection).Renungan teologi menjadi niscaya sehingga ada evaluasi tindakan untuk mengetahui kekurangan dalam strategi pembebasan.

Point penting lain dalam teologi pembebasan adalah Dalam teologi pembebasan mengambil dua dimensi sektor yang berhadapan atau berlawanan. Lebih jelas lagi dua sudut yang berlawanan dalam Teologi pembebasan itu sebagaimana

${ }^{10}$ Farid Essack, Membebaskan Yang Tertindas Al- qur'an, liberalisme, dan Pluralisme, Bandung: Mizan, 2000, hlm.121-122. 
disebutkan Hasan Hanafi adalah sisi yang dianiaya melawan penganiaya, yang miskin melawan yang kaya yang didiskriminasi melawan yang mendeskriminasi dan sejenisnya. ${ }^{11}$ Liberation Theology merupakan aspirasi kaum tertindas dan kelas sosial dengan menekankan konfliktual aspek ekonomi, sosial, agama, dan proses politik yang menjadikan mereka kecewa terhadap Negara atau kelas yang menindas.

Dalam pandangan Asghar, agama bisa mulai menebarkan sinarnya kembali sebagai harapan bagi masyarakat tertindas.Agama yang dulu turut andil dalam melanggengkan status quo, sekarang justru tampil sebagai pendorong anti kemapanan dan menjadi media yang efektif dari gerakan-gerakan yang revolusioner demi terciptanya masyarakat yang berkeadilan sekaligus menjadikan agama sebagai pembela kaum yang tertindas.

Ketika mendialektikakan fenomena sosial dengan al-Qur'an, Asghar memusatkan perhatiannya pada ketidakadilan yang berkembang di masyarakat. Baginya, ketidakadilan adalah akar permasalahan tertinggi dalam suatu masyarakat, karena itu ia harus diminimalisir, dan kalau perlu sebisa mungkin dieliminasi. Permasalahan semacam ini menurut Asghar sebenarnya sudah menggejala pasca meninggalnya Nabi.Islam yang dulunya bersifat revolusioner itu segera saja menjadi agama yang kental dengan status qou.

${ }^{11}$ Very Verdiansyah, Islam Emansipatoris, P3M: Jakarta, 2004, hlm. 29-33. 
Pada abad pertengahan misalnya, praksis feodalistik yang mendapat dukungan para ulama semakin terorganisir. Mereka para ulama lebih banyak menulis buku-buku tentang ibadah-ibadah ritual dan menghabiskan energi untuk mengupas masalah-masalah furu'iyah dalam syari'at, dan sama sekali mengecilkan arti penting Islam dalam menciptakan keadilan sosial dan kepedulian yang aktif terhadap kelompok yang lemah dan tertindas (mustad'afin). Dengan kondisi yang begini ini, maka wajar kalau Islam yang diterima masyarakat sekarang adalah Islam yang sarat dengan status quo.Selanjutnya kata Asghar, sekiranya semangat Islam masih menjadi ruh bagi masyarakat, maka seharusnya sistem kapitalisme yang didasarkan atas eksploitasi terhadap sesama manusia harus dihapuskan. ${ }^{12}$

\section{Reinterpretasi Quran Asghar Ali Engineer; Kesetaraan Gender}

\section{Kedudukan Perempuan dalam Islam}

Pada zaman Nabi, untuk pertama kalinya perempuan Arab mendapatkan banyak hak yang sebelumnya tidak terbayangkan.Perempuan pada masa itu dalam posisi sub-ordinat yangsangat lemah.Nabi menetapkan perempuan bisa mewarisi, bisa mempunyai hak milik sendiri, bisa minta cerai dan bisa menentukan dirinya sendiri. Pada sisi lain, poligini yang sebelumnya tanpa batas, kemudian dibatasi maksimal empat istri.

${ }^{12}$ Very Verdiansyah, Islam Emansipatoris, P3M: Jakarta, 2004, hlm. 24-29. 
Itupun dengan persyaratan yang ketat.Sedangkan poliandri dengan tegas dilarang. ${ }^{13}$

Selain itu, Nabi Muhammad merubah perlakuan masyarakat terhadap anak perempuan.Jika sebelumnya masyarakat Arab mempunyai tradisi mengubur anak perempuannya hidup-hidup karena rasa malu, maka Nabi kemudian melarang tradisi itu sekaligus merubah stigma negatif terhadap anak perempuan.

Namun sayangnya sekarang, Islam menjadi salah satu agama yang paling banyak mendapat sorotan kaitannya terhadap status dan aturan yang diberikan agama ini terhadap kaum perempuan. Hegemoni Islam terhadap perempuan muslin di negara-negara Islam terlihat jelas dalam praktik keseharian di panggung kehidupan, di mana kaum perempuan mendapat kesulitan dalam bergaul, mengekspresikan kebebasan individunya, terkukung oleh aturan yang sangat membatasi ruang kerja dan gerak dinamisnya. Di awal tulisannya Asghar Ali Engineer mengatakan, "Demi mengekalkan kekuasaan atas perempuan, masyarakat sering kali mengekang norma-norma adil dan egaliter yang ada dalam alQur'an". ${ }^{14}$ Bahkan dengan program islamisasinya dengan memaksa kaum perempuan masuk kembali ke rumah, menutup seluruh tubuh mereka dan mengekang mereka dengan peraturan yang memberatkan. ${ }^{15}$

\footnotetext{
${ }^{13}$ Asghar Ali Engineer, Islam dan Teologi Pembebasan,...hlm. 47.

${ }_{14}$ Asghar Ali Engineer, Hak-hak Perempuan dalam Islam, terj. Farid Wajidi dan Cici Farkha Assegaf, Yogyakarta: Pustaka Pelajar, 2000, hlm. 1.

${ }^{15}$ Dadang S. Anshori, Membicangkan Femenisme, Bandung: Pustaka Hidayah, 1997, hlm. 102.
} 
Agama Islam sebagai agama yang meletakkan manusia pada posisi yang sama, tidak peduli baik itu laki-laki dan perempuan. Allah Swt. pun berfirman makhluk yang paling dekat di sisi-Nya kelak bukanlah laki-laki atau peempuan, melainkan manusia yang paling bertaqwa, bisa laki-laki atau perempuan, seperti Q.S. alHujurat ayat 13: "Hai manusia, Sesungguhnya kami menciptakan kamu dari seorang laki-laki dan seorang perempuan dan menjadikan kamu berbangsa - bangsa dan bersuku-suku supaya kamu saling kenal-mengenal.Sesungguhnya orang yang paling mulia diantara kamu disisi Allah ialah orang yang paling taqwa diantara kamu.Sesungguhnya Allah Maha mengetahui lagi Maha Mengenal”.

Wahbah Zuhaili memberikan penjelasan terhadap ayat di atas, bahwa manusia diciptakan dengan asal yang jiwa yang satu dari Adam dan Hawa' dan semua kedudukannya sama (mutasawiyun). Oleh sebab itu harus menjunjung persatuan jangan saling menyombongkan diri.Karena yang paling mulia di sisi Allah yaitu yang paling bertaqwa, bukannya orang kaya maupun yang berkuasa. ${ }^{16}$ Demikian Ahmad Mustofa al-Maraghi menjelaskan bahwa hanya Allah Tuhan kalian, orang tua kalia satu (Adam dan Hawa'), tidak ada perbedaan antara orang Arab dengan 'Ajam, orang putih dengan orang hitam- kedudukanny sama- yang membedakan adalah ketaqawaan. ${ }^{17}$

${ }^{16}$ Wahabah Zuhaili, Tafsir al-Munir,fi al-Aqidah, wa as-Sayari'ah wa alManhaj, Suriah: Dar al-Fikr, 2000, jilid 13, hlm. 590.

${ }^{17}$ Ahmad Mustofa al-Maraghi, Tafsir al-Maraghi, jilid 9, t.tt: Dar al-Fikr, t.th. hlm. 143, 
Ini dilakukan dengan tujuan menciptakan kehidupan yang seimbang antara laki-laki dan perempuan.Sekalipun secara histories telah terjadi dominasi peran laki-laki yang menyebabkan doktrin ketidakadilan antara laki-laki dan perempuan.Dominasi peran lakilaki itu, menurut Asghar Ali dibenarkan oleh norma-norma kitab suci yang ditafsirkan oleh laki-laki untuk mengekalkan dominasi mereka sendiri. ${ }^{18}$

Asghar Ali Engineer menegaskan konsep kesetaraan status laki-laki dan perempuan dalam al-Qur'an secara normatif. Konsep kesetaraan itu mengisyaratkan dua hal: pertama, dalam pengertian yang umum, ini berarti penerimaan martabat kedua jenis kelamin dalam ukuran yang setara. Kedua, orang harus mengetahui bahwa laki-laki dan perempuan mempunyai hak-hak yang setara dalam bidang sosial, ekonomi, dan politik. Keduanya harus memiliki hak untuk memiliki atau mengatur harta miliknya tanpa campur tangan orang lain. Keduanya harus bebas memiliki profesi atau cara hidup, serta keduanya harus setara dalam tanggung jawab dalam segala hal. ${ }^{19}$ Hal ini pula yang dilakukan oleh Riffat Hasan yang mencoba mencermati dari dimensi teologis. Bahwa penjajahan laki-laki terhadap perempuan dilakukan secara in-human, mendapat

${ }^{18}$ Yunahar Ilyas, Feminisme dalam Kajian Tafsir al-Qur'an Klasik dan Kontemporer, Yogyakarta: Pustaka Pelajar, 1998, hlm. 4.

${ }^{19}$ Asghar Ali Engineer, Hak-hak Perempuan dalam Islam...hlm. 65. 
legitimasi teologis, meski sangat interpretatif tetapi setidaknya tetap menyudutkan perempuan pada posisi derivatif. ${ }^{20}$

Di samping itu Asghar Ali Engineer menjelaskan bahwa alQur'an juga memberikan tempat yang sangat terhormat bagi seluruh manusia, yang mencakup laki-laki dan perempuan. Hal ini didasarkan pada ayat al-Qur'an yang menyebutkan bahwa status keagamaan perempuan sebagaimana status sosial mereka, sama tingginya dengan laki-laki. Konsep ini dapat dililhat dalam Q.S. alAhzab ayat 35;

"Sesungguhnya laki-laki dan perempuan yang muslim, laki-laki dan perempuan yang mukmin, laki-laki dan perempuan yang tetap dalam ketaatannya, laki-laki dan perempuan yang benar, laki-laki dan perempuan yang sabar, laki-laki dan perempuan yang khusyuk, lakilaki dan perempuan yang bersedekah, laki-laki dan perempuan yang berpuasa, laki-laki dan perempuan yang memelihara kehormatannya, laki-laki dan perempuan yang banyak menyebut (nama) Allah, Allah Telah menyediakan untuk mereka ampunan dan pahala yang besar.

Adapun yang menjadi sebab turunnya ayat ini, bahwa ada seorang perempuan Anshar bernama Ummi Ummarah datang kepada Nabi, lalu mengatakan apa yang terasa di hatinya; "aku lihat segala sesuatunya hanya disebutkan untuk laki-laki, tidak ada sedikit juga tersebut perempuan". Lalu permasalahan yang dirasa oleh Ummi Ummarah itu terobati dengan ayat yang turun

${ }^{20}$ Adi Wicaksono, Teologi Perempuan; Dekonstruksi dan Wacana Patriakhi dalam Postmodernisme dan Masa Depan Peradaban, Jakarta, Aditiya Media, 1994, hlm. 45. 
ini."sesungguhnya laki-laki dan perempuan yang Muslim", sampai akhir ayat. ${ }^{21}$

\section{Konsep Teologi Pembebasan Asghar Ali Engineer}

Seperti yang sudah disinggung sebelumnya, sangat tidak berdaya di dunia Arab secara khusus dan di seluruh dunia secara umum.Namun demikian Rasulullah Saw.dengan ketentuan Q.S. AlBaqarah ayat 228 mendeklarasikan hak-hak perempuan, di mana sebelumnya belum pernah mereka dapatkan dalam aturan yang legal.

"Wanita-wanita yang ditalak handaklah menahan diri (menunggu) tiga kali quru'22.tidak boleh mereka menyembunyikan apa yang diciptakan Allah dalam rahimnya, jika mereka beriman kepada Allah dan hari akhirat. dan suami-suaminya berhak merujukinya dalam masa menanti itu, jika mereka (para suami) menghendaki ishlah. dan para wanita mempunyai hak yang seimbang dengan kewajibannya menurut cara yang ma'ruf. akan tetapi para suami, mempunyai satu tingkatan(derajat) ${ }^{23}$ kelebihan daripada isterinya. dan Allah Maha Perkasa lagi Maha Bijaksana”.

${ }^{21}$ Hamka, Tafsir Al-Azhar, Singapura: Pustaka Nasional PTE LTD, 2003, Cet .V. hlm. 5713.

${ }^{22}$ Tiga Quru', ulama bermazdhab Hanafi memahami dalam arti tiga kali haid. Jika demikian, yang dicerai oleh suaminya, sedang ia telah pernah bercampur dengannya dan dalam saat yang sama dia belum memasuki masa meopause, setalah dicerai tidak boleh kawin dengan pria lain, kecuali setelah mengalami tiga kali haid. Berbeda dengan madzhab Malik dan Syafi'i yang mengartikan tiga kali suci.Suci yang dimaksud adalah masa antara dua haid. Lihat M. Quraish Shihab, Tafsir al-Misbah: Pesan ,Kesan dan Keserasian al-Qur'an, Jakarta: Lentera Hati, 2002, vol. 1, hlm. 593.

${ }^{23}$ Derajat dimaksud adalah derajat kepemimpinan, tetapi kepemimpinan yang berlandasakan kelapangan dada suami untuk meringankan sebagian 
Pada saat al-Qur'an turun itulah pertama kalinya keberadaan individu perempuan sebagai makhluk hidup diterima tanpa ada persyaratan.Perempuan dapat melangsungkan pernikahan, dapat meminta cerai kepada suaminya tanpa persyaratan diskriminatif, dapat mewarisi harta ayah, ibu dan saudaranya yang lain, dapat memiliki harta sendiri dengan hak penuh, dapat merawat anakanaknya hingga dewasa. ${ }^{24} \mathrm{Di}$ Eropa perempuan tidak berhak memiliki harta hingga akhir abad ke 19, sedangkan di Amerika Serikat, perempuan baru mempunyai hak pilih pada sekitar tahun 1920.

Jika perempuan dikatakan menderita karena suaminya boleh menikah lebih dari satu wanita, itu hanya sebuah stigma.Tidak dapat disangkal bahwa stigma itu memang merendahkan status perempuan, yang sesungguhnya sederajat dengan laki-laki.Tetapi laki-laki Arab memiliki kebiasaan menikah dengan banyak istri dan Islam datang membatasi hanya sampai empat.

Mengenai hak, peran dan kedudukan perempuan, Asghar Ali dengan berpegang pada surat al-Ahzab ayat 35, seperti yang sudah diungkap di atas, menyatakan bahwa ayat tersebut berulang sepuluh kali menyatakan bahwa perempuan memiliki kesempatan

kewajiabn istri, seperrti yang diungkap oleh Guru Besar Mufasir ath-Thabari, walaupun ayat ini disusun dalam redaksi berita, tapi maksudnya perintah bagi suami untuk memperlakukan istri mereka dengan sikap terpuji, agar memperoleh derajat itu. Lihat M. Quraish Shihab, Tafsir al-Misbah: Pesan ,Kesan dan Keserasian al-Qur'an...hlm. 596-597.

${ }^{24}$ Asghar Ali Engineer, Islam dan Teologi Pembebasan,...hlm. 50. 
yang sama dengan laki-laki dalam mencapai tingkat kebaikan. Hal ini senada dengan mufasir Maulana Muhammad Ali. ${ }^{25}$

Sekalipun secara normatif al-Qur'an memihak kepada kesetaraan status antara laki-laki atas perempuan, tetapi secara kontekstual al-Qur'an memang menyatakan adanya kelebihan tertentu kaum laki-laki atas perempuan. Menurut Asghar Ali Engineer, kelebihan dan keunggulan yang dimiliki laki-laki atas perempuan itu bukan karena jenis kelamin, akan tetapi karena konteks sosialnya.

Asghar Ali Engineer mengkritik dengan tajam metode para mufasir yang memahami ayat hanya semata-mata bersifat teologis dengan mengabaikan pendekatan sosiologis. Faktanya pula masalah yang muncul dalam soal ini lebih banyak lahir dari proses sosialisasi, termasuk sosislilsasi nilai-nilai agama, tradisi sebenarnya yang memperngaruhi cara penafsiran kepada ayat dan teks ini adalah patriarkhi demikian yanng dikatakan Riffat Hasan ${ }^{26}$. Menurut Asghar Ali Engineer, seharusnya para mufasir menggunakan pandangan secara sosio-teologis. Sehingga ia mengungkapkan:

"Meskipun demikian Al-Qur'an memang berbicara tentang lakilaki yang memiliki kelebihan dan keunggulan sosial atas perempuan. Ini sebagaimana ditunjukan di atas, harus dilihat dalm konteks sosialnya yang tepat. Struktur sosial pada zaman Nabi tidaklah benar-

${ }^{25}$ Asghar Ali Engineer, Hak-hak Perempuan dalam Islam...hlm. 68.

${ }^{26}$ Budhy Munawir Rachman, Femenisme Agenda Baru Pemikiran Islam, Ulum al-Qur'an no.3, vol. IV, 1995, hlm 53. 
benar mengakui kesetaraan laki-laki dan perempuan.Orang tidak dapat mengambil pandangan yang semata-mata teologis dalam hal semacam ini.Orang harus menggunkan pandangan sosialteologis.Bahkan Al-Qur' an pun terdiri dari ajaran yang kontekstual dan juga normatif. Tidak ada kitab suci yang efektif, jika mengabaikan konteknya sama sekali. ${ }^{27}$

Menurut Riffat Hasan, setidaknya ada dua jalan untuk mencapai pembebasan perempuan: Pertama, melakukan dekonstruksi terhadap tradisi Islam, yaitu penataan ulang bahwa konstruksi teologis yang misoginis yang disebabkan pengaruh budaya Arab para Islam yang misoginis dan bias anti perempuan yang diserap Islam dari tradisi agama Kristen dan Yahudi. Kedua, reinterpretasi ayat-ayat al-Qur'an, ini dilakukan dengan cara menguasai bahasa al-Qur'an dan tidak memperlakukan teks sebagai proof texts. ${ }^{28}$ Tetapi menempatkan pada konteks yang tepat. Kemudian untuk interpretasi harus bertumpu pada akar kata,"karena bahasa Arab sebagaimana bahasa Semit yang lain sangat bertumpu pada akar kata". ${ }^{29}$

\section{Asghar Ali Engineer dan Wacana Ketidaksetaraan Gender}

\section{a. Konsep Pewarisan}

Menurut Asghar Ali Engineer dalam hal pewarisan memang anak perempuan mendapat separuh dari yang didapat oleh laki-

${ }^{27}$ Asghar Ali Engineer, Hak-hak Perempuan dalam Islam...hlm. 68.

${ }^{28}$ Dianggap sebagai dalil-dalil keagamaan yang berharga mati. hlm. 76 .

29 Wardah Hafidz, Aliran-aliran Feminisme, Jakarta: Paramadina, 1995, 
laki, maka bukan berarti bahwa penerima yang lebih sedikit dianggap lebih rendah derajatnya, karena pewarisan sangat berbeda sekali dengan kesetaraan antara laki-laki dan perempuan..$^{30}$

Selanjutnya Asghar Ali Engineer mengatakan, bagian yang demikian sangat tergantung pada struktur sosial-ekonomi dan fungsi jenis kelamin dalam masyarakat.Telah menjadi prinsip dalam Islam yang diambil dari al-Qur'an bahwa seorang istri harus diberi nafkah oleh suaminya walaupun dia memiliki harta yang banyak.Ia sama sekali tidak berkewajiban membelanjakan kekayaannya sendiri dan telah menjadi haknya untuk menuntut nafkah dari suaminya. Tidak hanya itu, dia juga mendapat maskawin dari suaminya, dan itu menjadi kewajiban bagi suami.

Dengan demikian Asghar Ali Engineer melihat bahwa tidak ada ketentuan yang bersifat diskriminatif terhadap perempuan.Karena selain mendapat warisan, nanti anak perempuan itu mendapatkan tambahan harta berupa mahar atau maskawin dari suaminya.Padahal dia tidak mempunyai kewajiban apapun untuk menafkahi dirinya dan anaknya, karena semua menjadi tanggung jawab suaminya. ${ }^{31}$

\section{b. Konsep Kesaksian}

Terkait masalah kesaksian, Asghar Ali Engineer mengatakan hal ini menjadi isu yang diperdebatkan dalam teologi Islam, terutama yang telah dinyatakan dalam Q.S. Al-Baqarah ayat

${ }^{30}$ Asghar Ali Engineer, Hak-hak Perempuan dalam Islam...hlm. 107.

${ }^{31}$ Yunahar Ilyas, Feminisme dalam Kajian Tafsir al-Qur'an Klasik dan Kontemporer,...hlm. 44 . 
282.Para fuqaha mendiskusikan ataran umum, yaitu satu saksi lakilaki setara nilainya dengan dua saksi perempuan.

Menurut Asghar Ali Engineer, bahwa ayat ini berkaitan dengan masalah keuangan. Perempuan di masa itu tidak mempunyai pengalaman yang memadai dalam masalah keuangan, karena itu dua saksi perempuan dianjurkan oleh Al-Qur'an. Sehingga bila kelupaan (kurang pengalaman), maka salah satu orang dapat mengingatkan yang lain. Karena laki-laki mempunyai pengalaman yang cukup, maka pengingat semacam itu tidak perlu bagi mereka. ${ }^{32}$

Terpenting bagi Asghar Ali Engineer bahwa walaupun dua saksi perempuan yang dianjurkan sebagai pengganti seorang saksi laki-laki, hanya salah seorang diantara keduanya yang memberikan kesaksian, fungsi yang lain tidak lebih hanya sekedar mengingatkan jika yang satunya bimbang karena kurang pengalaman terkait masalah keuangan.

\section{c. Konsep Poligami}

Masalah poligami sekarang dianggap sebuah persoalan controversial yang bersumber dari agama.Karena memang secara legal formal agama memperbolehkan adanya poligami atau menikahi lebih dari seorang istri secara bersama. Ketentuan tersebut telah dinyatakan dalam Q.S. An-Nisa' ayat 3;

"Dan jika kamu takut tidak akan dapat berlaku adil terhadap (hak-hak) perempuan yang yatim (bilamana kamu mengawininya), Maka

${ }^{32}$ Asghar Ali Engineer, Hak-hak Perempuan dalam Islam...hlm. 97. 
kawinilah wanita-wanita (lain) yang kamu senangi : dua, tiga atau empat. Kemudian jika kamu takut tidak akan dapat berlaku adil, Maka (kawinilah) seorang saja, atau budak-budak yang kamu miliki. yang demikian itu adalah lebih dekat kepada tidak berbuat aniaya.

Untuk memahami esensi yang benar terhadap ayat di atas, menurrut Asghar Ali Engineer harus mempertimbangkan ayat yang sebelumnya ( an-Nisa: 2) dan setelahnya (an-Nisa: 127). dari ayat tersebut jelaslah bahwa ayat diperbolehkannya poligami diturunkan dalam konteks anak yatim maupun istri-istrinya jika orang yang menjadi wali tersebut menikahi lebih dari satu.

Jika dilihat konteks sosialnya, maka ayat-ayat tentang poligami bukanlah izin umum kepada laki-laki untuk menikah lebih satu dengan semaunya.Poligami diperbolehkan hanya untuk menjamin keadilan bagi anak yatim atau perempuan (janda). Hal ini artinya jika persoalan itu tidak ada, maka poligami tidak akan muncul sama sekali. Menurut Asghar Ali Engineer, apa yang dimaksud perlakuan yang adil di sini, tidak hanya pada aspek fisik, tapi juga aspek non fisik, seperti cinta dan afeksi. ${ }^{33}$

Senada dengan M. Quraish Shihab, bahwa ayat ini tidak mewajibkan poligami atau menganjurkannya, ia hanya berbicara tentang bolehnya poligami dan itupun merupakan pintu kecil yang

${ }^{33}$ Semacam status kejiwaan yang disebabkan oleh pengaruh eksternal.Lebih sering digunakan untuk menjelaskan hubungan dua orang atau lebih darei sekedar rasa simpati dan persahabatan. 
hanya dapat dilalui oleh yang amat sangat membutuhkan dan dengan syarat yng tidak ringan. ${ }^{34}$

Dalam pandangan Asghar Ali Engineer, syarat perlakuan adil mempunyai tiga tingkat yang harus dipenuhi: pertama, jaminan untuk menggunakan harta anak yatim dan janda secara benar, kedua, jaminan untuk memberikan keadilan kepada istri dalam hal materi, ketiga, memberikan cinta dan kasih sayang yang sama kepada semua istrinya. ${ }^{35}$

Meskipun Asghar Ali Engineer mengakui bahwa al-Qur'an secara tegas telah mengakui kesetaraan antara laki-laki dan perempuan, Asghar juga tidak menafikan keunggulan laki-laki atas perempuan dalam beberapa persoalan yang bersifat normatif. ${ }^{36}$

\section{d. Posisi dalam Keluarga}

Berbicara tentan perempuan, Al-Qur'an secara tegas mengakui perempuan sebagai entitas yang sah dan Al-Qur'an juga memberi mereka hak dalam perkawinan, perceraian, harta dan warisan. Hal ini dipertegas dalam surat at-Taubah ayat 71 menyatakan di mata Tuhan perempuan dan laki-laki memiliki status yang sama. Hal ini diperkuat juga dalam surat al-Ahzab ayat 35.

Asghar Ali Engineer menyatakan bahwa perempuan tidak hanya memiliki hak untuk mencari penghasilan, tetapi juga apa

${ }^{34}$ M. Quraish Shihab, Tafsir al-Misbah: Pesan ,Kesan dan Keserasian alQur'an...hlm. 341.

${ }^{35}$ Asghar Ali Engineer, Hak-hak Perempuan dalam Islam...hlm. 154.

${ }^{36}$ Seperti yang telah tekstual tertulis dalam Al-Qur'an, misalnya menjadi imam sholat, konsep waris, dll. 
yang telah diusahakan tersebut menjadi milik mereka sendiri. Hasil tersebut tidak bisa dibagi dengan suaminya kecuali dengan keinginan perempuan itu sendiri.

Terkait posisi perempuan dalam keluarga, Asghar Ali Engineer juga melakukan kritik terhadap mufasir ortodok yang telah melakukan diskriminasi terhadap kehidupan istri dalam keluarganya. Kritik ini dilakukan karena para mufasirin tersebut selalu bersembunyi dalam menafsirkan kata qawwamdalam surat an-Nisa' ayat 34:

"Kaum laki-laki itu adalah pemimpin bagi kaum wanita, oleh karena Allah telah melebihkan sebahagian mereka (laki-laki) atas sebahagian yang lain (wanita), dan karena mereka (laki-laki) telah menafkahkan sebagian dari harta mereka.sebab itu Maka wanita yang saleh, ialah yang taat kepada Allah lagi memelihara diri ketika suaminya tidak ada, oleh karena Allah telah memelihara (mereka). wanita-wanita yang kamu khawatirkan nusyuznya, Maka nasehatilah mereka dan pisahkanlah mereka di tempat tidur mereka, dan pukullah mereka. kemudian jika mereka mentaatimu, Maka janganlah kamu mencaricari jalan untuk menyusahkannya. Sesungguhnya Allah Maha Tinggi lagi Maha besar.( an-Nisa'/4:34).

Qawwam dalam penjelasan M. Quraish Shihab dengan pemimpin, akan tetapi terjemahan itu belum menggambarkan seluruh makna yang dikehendaki, walau harus diakui bahwa kepemimpinan merupakan aspek yang dikandungnya. Atau dengan kata lain dalam pengertian "kepemimpinan" tercakup pemenuhan 
kebutuhan, perhatian, pemeliharaan, pembelaan, dan pembinaan. ${ }^{37}$ Demikian pula Hamka memberikan makna Qawwam dengan pemimpin, sebab laki-laki itulah yang memimpin perempuan, bukan perempuan yang memimpin laki-laki, dan bukan sama pula kedudukannya. ${ }^{38}$

Engineer mencoba menafsirkan kata qawwam tersebut dengan metodologi yang telah ia bangun, yaitu membedakan ayat normatif dan kontekstual serta memahami sosio-teologis ketika ayat tersebut diturunkan.

Untuk memahami konteks pewahyuan, Engineer mengutip pendapat al-Zamakhsyari. Menurut beliau ayat ini berhubungan kasus pemimpin Anshar, Sa'ad bin Rabi' yang menampar istrinya yang bernama Habibah binti Zaid dengan alasan karena sang istri tidak taat kepada suaminya. Habibah lalu mengadu kepada ayahnya dan kemudian masalah ini dibawa kehadapan Rasulullah. Rasulullah memberi nasihat untuk membalas perbuatan suaminya tersebut. Namun demikian, banyak laki-laki Madinah yang tidak setuju dan keberatan dengan nasihat tersebut. Rasulullah sangat paham bahwa oposisi mereka terhadap nasihat beliau tersebut dipengaruhi oleh struktur sosial yang didominasi laki-laki.

${ }^{37}$ M. Quraish Shihab, Tafsir al-Misbah: Pesan ,Kesan dan Keserasian alQur'an...vol. 2,hlm. 424-425.

${ }^{38}$ Hamka, Tafsir Al-Azhar, Singapura: Pustaka Nasional PTE LTD, 2003, hlm. 1195. 
Kemudian turunlah ayat tersebut yang membatasi scope kekerasan terhadap perempuan. 39

Qawwamjuga seringkali dipakai untuk menunjukkan superioritas laki-laki atas perempuan. Menurut Engineer, superioritas yang diberikan kepada laki-laki tersebut pada dasarnya bukanlah melambangkan kelemahan jenis kelamin perempuan, tetapi menunjukkan laki-laki sebagai pencari nafkah..$^{40}$ Sedangkan melihat keadaan sosial pada masa itu, dalam masyarakat Arab perempuan tidak diharapkan atau diwajibkan untuk mencari nafkah dan menjaga keluarga. Semua pekerjaan tersebut secara eksklusif adalah kewajiban dan wilayah kerja laki-laki. Dalam konteks sosiologis, hal tersebut tidak bisa dibalik. Karena laki-laki ditugasi dengan kewajiban untuk menjaga keberlangsungan keluarga, maka ia juga diberi superioritas satu tingkat di atas perempuan.

Sementara Asghar Ali Engineer sendiri memahami qawwam sebagai kewajiban laki-laki untuk menjaga perempuan. ${ }^{4}$ Selain itu juga dikupas kata qanitat dan nusyuz.Kata qanitatdiartikan sebagai ketaatan manusia kepada Tuhan maupun kepada suami, sedangkan nusyuz sebagai melawan suami dengan tujuan penuh dosa.Di samping itu Asghar Ali Engineer mengutip pendapat Parvez (mufasir dari Pakistan), bahwa makna nusyuz harus dipahami sebagai istri dan suami.

${ }^{39}$ M. Agus Nuryatno, Islam, Teologi Pembebasan dan Kesetaraan Gender Studi atas Pemikiran Engineer Ali Engineer, hlm. 70.

${ }^{\circ} \mathrm{M}$. Agus Nuryatno, Islam, Teologi Pembebasan dan Kesetaraan Gender Studi atas Pemikiran Engineer Ali Engineer, hlm. 70.

${ }^{41}$ Asghar Ali Engineer, Pembebasan Perempuan...hlm. 66-67. 
Merupakan pandangan yang tidak Qur'ani menurur Asghar Ali Engineer, ketika membatasi perempuan pada persoalan rumah tangga. Bagi Asghar, seorang perempuan dapat memainkan peranan apapun dalam hidup (termasuk kehidupan keluarga) tanpa melanggar hudud Allah Swt. ${ }^{42}$ Dalam ekonomi industrial modern perempuan harus memainkan peranan yang semakin besar. Mereka harus bekerja untuk menjamin kehidupan keluarga yang sejahtera. Secara keseluruhan al-Qur'an pada dasarnya mengakui kesetaraan antara perempuan dan laki-laki dalam kehidupan keluarga, sebagaimana dijelaskan dalam surat al-Baqarah ayat 23 menyatakan "janganlah seseorang ibu menderita kesengsaraan karena anaknya dan seoranng ayah karena anaknya". 43

Pada akhirnya Asghar menganggap bahwa meskipun alQur'an memuliakan perempuan setara dengan laki-laki, namun semangat itu ditundukkan oleh patriarkisme yang telah mendarah daging dalam kehidupan berbagai masyarakat, termasuk kaum muslimin.Meskipun secara normatif dapat diketahui bahwa alQur'an memihak kepada kesetaraan status antara kedua jenis kelamin, secara kontekstual al-Qur'an mengakui adanya kelebihan laki-laki di bidang tertentu dibanding perempuan.

Akan tetapi dengan mengabaikan konteksnya, fuqaha berusaha memberikan status lebih unggul bagi laki-laki. Dalam proses pembentukan syari'ah, ayat-ayat yang berkaitan dengan masalah perempuan sering ditafsirkan sesuai dengan prasangka-

${ }^{42}$ Asghar Ali Engineer, Hak-hak Perempuan dalam Islam...hlm. 126.

${ }^{43}$ Asghar Ali Engineer, Hak-hak Perempuan dalam Islam...hlm. 222. 
prasangka yang diadopsi oleh bangsa Arab dan non Arab para Islam, yaitu peradaban Hellenisme dan Sassanid mengenai perempuan. Dengan demikian, interpretasi ayat-ayat al-Qur'an sangat tergantung pada sudut pandang dan posisi apriori yang diambil penafsirnya.

Asghar Ali berpandangan bahwa Allah Swt. tidak melebihkan laki-laki atas perempuan.Dari penjelasan di atas, tampaknya Asghar ingin mengatakan bahwa dalam kahzanah tafsir, khususnya yang berkaitan dengan masalah perempuan, sebenarnya ada pendapat-pendapat yang bersikap empati atau properempuan.Meskipun harus diakui, pendapat yang demikian kalah populer dibanding dengan pendapat-pendapat lain yang misoginis.Atas dasar empati inilah Asghar mencoba menunjukkan alternatif tafsiran atas beberapa ayat Al-Qur'an yang selama ini digunakan untuk mengekalkan subordinasi perempuan, yaitu berkaitan dengan perceraian, perkawinan, hak waris, kesaksian dan lain-lain. ${ }^{4}$ Subordinasi perempuan ini seharusnya juga dilihat dalam konteks sosiologis.jika masyarakat atau konteks berubah, maka subordinasi ini harus ikut berubah.

\section{Kesimpulan}

Dalam memahami ayat-ayat yang berbicara tentang perempuan, Asghar Ali Engineer mempunyai 3 metode, yaitu Membedakan ayat-ayat al-Qur'an yang mempunyai aspek normatif dan kontekstual, Penafsiran ayat-ayat al-Qur'an sangatlah

${ }^{44}$ Asghar Ali Engineer, Hak-hak Perempuan dalam Islam...hlm. 220. 
tergantung kepada persepsi, pandangan dunia, pengalaman, dan latar belakang sosio-kultural di mana mufassir itu tinggal, dan Makna ayat-ayat al-Qur'an itu terbentang oleh waktu.

Dari pemaparan pemikiran Asghar sekaligus contoh penafsirannya, maka dapat diketahui bahwasannya ia mencoba reinterpretasi al-Qur'an dengan melakukan kontekstualisasi teologi dalam wacana kontemporer yang cenderung bernuansa induktif-historis. Pada akhirnya dapat ditunjukkan oleh Asghar bahwasanya tidak ada konsep inferior-inferior dalam Islam. Konsep yang dibangun adalah konsep egalitarian dan kesetaraan. Hubungan atau relasi laki-laki dan perempuan dalam Islam adalah lebih bersifat komplementer dan bukan dominatif, baik oleh lakilaki maupun perempuan.

\section{DAFTAR PUSTAKA}

Al-Marāgī, Aḥmad Musțafa, Tafsīral-Marāgī,Mesir:MusțafaalBābal-Halabi,1394H/1974 M.

Anshori, Dadang S. Membicangkan Feminisme, Bandung: Pustaka Hidayah, 1997.

Dosen Tafsir Hadis Fakultas Ushuluddin IAIN Sunan Kalijaga.Studi Kitab Tafsir Kontemporer. Yogyakarta: TH Press, 2006.

E. Kusnadiningrat, Teologi dan Pembebasan, Gagasan Islam Kiri Hasan Hanafi, Jakarta: Logos, 1999.

Effendi, Djohan, "Memikirkan Kembali Asumsi Pemikiran Kita", dalam kata pengantar bukunya Asghar Ali Engineer, Islam 
dan Pembebasan, alih bahasa Hairus Salim dan Imam Baehaqy,Yogyakarta: Lkis, 1993.

Engineer, Asghar Ali ,Islam dan Pembebasan, terj. Hairus Salim dan Imam Baehaqy,Yogjakarta: LKiS, cet. VII, 2007.

Pembebasan Perempuan terj. Agus Nuryatno. Yogyakarta: LKiS Yogyakarta, 2007.

Hak-hak Perempuan dalam Islam, terj. Farid Wajidi dan Cici

Farkha Assegaf, Yogyakarta: Pustaka Pelajar, 2000.

Islam dan Teologi Pembebasan, Yogjakarta: Pustaka Pelajar, 1999.

Islam Masa Kini, Yogjakarta: Pustaka Pelajar, 2004.

Essack, Farid. Membebaskan Yang Tertindas Al quran,liberalismedan,Pluralisme, Bandung: Mizan, 2000.

Ibnu 'Ashur, Muhammad al-Tahir, Tafsir al-Tahrir wa al-Tanwir, t.tp.: Dar al-Tunisiyyah li al-Nashr, t.th.

Ibnu Kathir, Abi al-Fida' al-Isma'il Ibn 'Umar al-Dimashqi, Tafsir

al-Qur'an al-'Azhim, Beirut: Dar al-Kutub Ilmiyah, 1420 H/1999 M.

Ilyas, Yunahar.Kuliah 'Aqidah Islam, Jogjakarta:LPPI, 2000.

----------Feminisme dalam Kajian Tafsir al-Qur'an Klasik dan Kontemporer, Yogyakarta: Pustaka Pelajar, 1998.

Fakih, Mansour. Sesat Pikir Teori Pembangunan dan Globalisasi,Jogjakarta : Insist Press dan Pustaka Pelajar,2001. Hafidz, Wardah. Aliran-aliran Feminisme, Jakarta: Paramadina, 1995. 
Hamka, Tafsir Al-Azhar, Singapura: Pustaka Nasional PTE LTD, 2003, Cet. V.

Hanafi, HassanKiri Islam, dalam Kazuo Shimogaki, Kiri Islam Antara Modernisme dan Posmodernisme, Telaah Kritis atas Pemikiran Hassan Hanafi, terj. Imam Aziz dan Jadul Maula, Yogjakarta: LKIS, cet. VII 2007.

Kementerian AgamaRI, Al-quran dan Terjemahnya, Bandung:

Gema RisalahPress, 1989.

Lowy, Michael, Teologi Pembebasan,Yogjakarta: Pustaka Pelajar, 1999.

Maraghi, Ahmad Mustofa. Tafsir al-Maraghi, jilid 9, t.tt: Dar alFikr, t.th.

Nasr, Seyyed Hossein, dkk (ed), Ensiklopedi Tematis Filsafat Islam, Bandung:Mizan, cet. 1. 2003.

Nitiprawiro, Francis Wahono, Teologi Pembebasan, Sejarah, Metode,

Praksis dan Isinya, Yogjakarta: LKiS, cet. II, 2008.

Nuryatno, M. Agus. Islam, Teologi Pembebasan dan Kesetaraan Gender. Yogyakarta: UII Press, 2001.

Shihab, M. Quraish ,Tafsir al-Misbah: Pesan ,Kesan dan Keserasian alQur'an, Jakarta: Lentera Hati, 2002

Sj. JB. Banawiratma, dkk.Berteologi Sosial Lintas Imu, Yogyakarta: Kanisius, 1993.

Suseno, Frans Magnis, Pemikiran Karl Marx dari sosialisme Utopis ke Perselisihan Revisionisme, Jakarta: gramedi, 1999. 
Wardian.Saksi Wanita Menurut Asghar Ali Engineer dan Relevansinya dalam Akad Nikah.Skripsi Jurusan al-Ahwal al-Syakhsiyah Fakultas Syariah UIN Sunan Kalijaga, 2003.

Wicaksono, Adi. Teologi Perempuan; Dekonstruksi dan Wacana Patriakhi dalam Postmodernisme dan Masa Depan Peradaban, Jakarta, Aditiya Media, 1994.

Zuhaili, Wahabah. Tafsir al-Munir,fi al-Aqidah, wa as-Sayari'ah wa al-Manhaj, Suriah: Dar al-Fikr, 2000. 